\title{
Stem cell patenting in Europe - the twilight zone
}

\author{
DUNCAN CURLEY ${ }^{1}$
}

\section{Introduction}

Controversy often follows when patents are obtained in a pioneering area of technology. Patent filing activity in the field of regenerative medicine and in relation to stem cells in particular has not escaped opprobrium, although it is instructive to compare the nature of the debates that are taking place over the patenting of stem cells in the US and Europe. In the US, debate over the early patent applications made by the Wisconsin Alumni Research Foundation (WARF) has been intense ${ }^{2}$, but at least it appears to have been grounded firmly in patent law principles. In Europe, the debate has skewed away from the basic patent law tenets of novelty, inventiveness and industrial utility and has entered something of a twilight zone, with the European Patent Office (EPO) serving as a diffident forum for difficult moral and ethical arguments about the destruction of human embryos and the commercial exploitation of human life.

\section{The US Position - WARF}

The breadth of the claims relating to human stem cells in the early WARF patent filings has to date been the major focus of debate in the US. The WARF patent applications were filed after work carried out by James Thomson and co-workers at the University of Wisconsin-Madison in the 1990s. Thomson's team was the first to isolate human embryonic stem cells, as described in a publication in 1998 in Science ${ }^{3}$. The first WARF patent granted by the US Patent and Trademark Office (USPTO) in this area was US Patent No. 5843780, entitled "Primate Embryonic Stem Cells". It claimed (inter alia) "A purified preparation of primate embryonic stem cells" with certain characteristics. Further WARF patents granted by the USPTO were US Patent Nos. 6200806 and 7029913. The broad nature of the monopolies obtained by WARF has been described as embodying "one of the strongest possible property claims in the field of stem cells, establishing control at the very root of all possible lineages of cellular differentiation"4.

However, the validity of these three WARF patents was challenged in reexamination proceedings brought by the Foundation for Taxpayer and Consumer Rights, essentially on the ground that what was claimed was non-inventive and therefore unpatentable. In brief, the argument was that the techniques described in the WARF patents had previously been used to isolate embryonic stem cells in other mammals. As such, their application to human embryonic stem cells was rendered obvious. The USPTO accepted this argument in a decision that was issued in March $2007^{5}$.

\section{The European Position}

\section{Too Broad Patents?}

The issue of breadth of claims was addressed in a report produced by the European Group on Ethics in Science and New Technology (EGE) in $2002^{6}$. The EGE arrived 
at the conclusion that isolated, unmodified stem cells do not fulfil the legal requirements for patentability, particularly due to their lack of industrial application, because unmodified stem cells do not have one specific use but a very large range of potential undetermined uses: "Therefore, to patent such unmodified stem cell lines would...lead to too broad patents".

Underlying the EGE's statement about the undesirability of patents with broad scope was concern that they might stifle research and thereby restrict the benefits of any medical advances from being passed on to patients. The EGE emphasised in its report that patents are supposed to benefit society overall and this factor should be borne in mind when assessing the availability of patents. The EGE's position has come in for criticism $^{7}$, not least because it lacks a substantive basis in European patent law.

One of the legal requirements for patentability is that the breadth of granted patent claims should be commensurate with the inventor's contribution to technical development in a particular field ${ }^{8}$. In essence, broad patent claims should only be granted when an invention is deserving of them, such as, for example, a pioneering invention in a new area of technology. Concern about "too broad patents" is therefore not unique to stem cell technology.

Even though the remarks in the EGE's report may not have had a solid grounding in European patent law, it has recently been observed that the concern about awarding broad monopolies over stem cell technology without any specific proof of utility may have been quite apposite. This is because stem cells derived from embryos do not yet have an established, specific use: "their potential utility for repair of failing organs or tissues is dependent on the subsequent development of ways of coaxing the cells to differentiate" in a particular way".

Yet neither lack of utility nor lack of inventive step was the basis for the rejection by the European Patent Office of another early WARF patent, European patent application 96903521.1, in July 2004. Instead, the EPO Examining Division adopted a distinctly European position in relation to the WARF patent claims, based upon an expansive interpretation of the so-called "morality provisions" in the European Biotechnology Patent Directive ${ }^{10}$, the genesis of which will now be examined.

\section{The European Biotechnology Patent Directive}

The Biotechnology Patent Directive was first proposed by the European Commission in 1988. It was intended to be a harmonising measure, its purpose being to eliminate disparities between the Member States in the legal protection afforded to biotechnological inventions. After protracted debate and in the face of intense political opposition from animal welfare activists and environmentalists, in 1995 - at a time when public concern about developments in biotechnology in general was at its height - the first version of the Directive was vetoed by the European Parliament. In introducing a second draft of the Directive, the European Commission was suitably contrite and attempted to seek consensus by building in new provisions that were said to give due emphasis to the ethical aspects of patenting life forms.

The Biotechnology Patent Directive states in Article 5(1) that the human body, at the various stages of its formation and development, cannot be patented. The same directive also states that elements isolated from the human body or otherwise 
produced by means of a technical process (including, for example, a human gene) are not excluded from patentability, even when the structure of an element is identical to that of its natural counterpart, provided that the rights conferred by the patent in question do not extend to the human body in its natural state ${ }^{11}$.

Article 6 is the "failsafe" clause that is intended to prohibit the grant of patents the exploitation of which would offend against the morality of ordinary European citizens. It states as follows:

(1) Inventions shall be considered unpatentable where their commercial exploitation would be contrary to ordre publique or morality; however, exploitation shall not be deemed to be so merely because it is prohibited by law or regulation.

(2) On the basis of [the above] paragraph 1, the following, in particular, shall be considered unpatentable:

(a) processes for cloning human beings;

(b) processes for modifying the germ line genetic identity of human beings;

(c) uses of human embryos for industrial or commercial purposes;

(d) processes for modifying the genetic identity of animals which are likely to cause them suffering without any substantial medical benefit to man or animal, and also animals resulting from such processes.

The prohibition enshrined in Article 6(1) is derived from a long-standing tradition in European patent law, with origins dating back to early twentieth century international convention and beyond ${ }^{12}$, that is aimed at preventing the grant of patent monopolies for inventions that would be morally repugnant to the public, if exploited by the patentee. However, the exclusions in Article 6(2) have no deep-seated tradition in European patent law and arguably reflect instead a list of "hot" political issues that preoccupied MEPs by virtue of being prevalent in the popular news press in the 1990s, rather than a considered attempt to legislate for the future of the European patent system.

Article 6(2)(a) was intended to prohibit patents claiming techniques for the cloning of human beings, cloning being an aspect of biotechnology that has often excited the newspapers. It will be recalled that the Roslin Institute and Dolly the sheep had attracted a good deal of media coverage during 1997, as the second draft of the Directive was being considered. Article 6(2)(b) was intended to indicate a clear stance "on principle" against germ line gene therapy ${ }^{13}$. Article $6(2)(\mathrm{c})$ was probably another legacy of the emergence of nuclear transfer technology ${ }^{14}$. Article 6(2)(d) may have been the product of agitation by animal welfare activists, but in fact, the test laid down in this provision is arguably easier to apply than the previous test for the balancing of animal welfare against the perceived usefulness of an invention to man, as laid down in the EPO's caselaw in the Oncomouse case ${ }^{15}$.

Although the intention behind the list in Article 6(2) was ostensibly to provide clarity

Genomics, Society and Policy, Vol.4, No.3 (2008) ISSN: 1746-5354

(C) ESRC Genomics Network. 
to the scope of the general exclusion in Article 6(1), concerns were expressed at an early stage in the life of the Biotechnology Patent Directive that the reality might be somewhat different ${ }^{16}$.

\section{Interpreting Article 6}

The Biotechnology Patent Directive is a piece of European Union legislation and so the ultimate authority for interpretation of its provisions is the European Court of Justice in Luxembourg. The Court of Justice has already held that Article 6(1) gives the administrative patent-granting authorities (ie, the national patent offices) within the European Union a wide scope for manoeuvre in applying the exclusion ${ }^{17}$. In theory, this should allow the national patent offices to take account of particular social and cultural concerns that the exploitation of certain types of technology might give rise to in their respective countries. For example, in the UK, where the climate for stem cell research is positive and the production of new human embryonic stem cell lines is legal, the UK Intellectual Property Office has taken the proactive step of publishing guidance on how it will treat UK patent applications for inventions involving human embryonic stem cells ${ }^{18}$.

Although the Article 6 provisions of the Biotechnology Patent Directive were incorporated into the Implementing Regulations to the European Patent Convention (EPC) in 1999, with the intention of aligning the EPC with the Directive, it should be noted that the EPO is an autonomous institution. It is not a body whose decisions are subject to judicial review by the European Community courts. This has not presented a problem in the interpretation of Article 6(1), which, as indicated above, was based on an existing provision of the European Patent Convention with a solid legal foundation ${ }^{19}$ that had already been subject to interpretation in the EPO's caselaw ${ }^{20}$. It is the lack of a jurisprudential track record in the interpretation of the provisions of Article 6(2) that has given rise to recent problems in Europe, with the EPO having become (almost by default) the final arbiter of what these provisions mean, even though they were the product of the convoluted and highly politicised legislative passage of the Biotechnology Patent Directive through the European Union's lawmaking institutions.

Since most patents for biotechnological inventions are filed at the EPO in Munich (for reasons both of cost and convenience), the consequence of a broad interpretation by the EPO of the exclusions in Article 6(2) would be to take away the room for manoeuvre that was intended to be given to the national patent offices in the Member States by means of Article 6(1). As we shall see, the Enlarged Board of Appeal has recently held that a broad interpretation of Article 6(2)(c) is indeed appropriate, but before turning to the cases, it is necessary to explain briefly some of the scientific terminology.

Mammalian stem cells can be classified in two main ways: by the source from which they are isolated and by the extent to which they can form different cell types (differentiation). Adult stem cells are found in adult tissues, such as bone marrow. Embryonic stem cells are found in the blastocyst, the ball of cells that constitutes an embryo. Totipotent stem cells can be differentiated into any cell type in the body. Human totipotent stem cells can be isolated from a human embryo at between four to six days after fertilization, during the first divisions of a fertilized egg. Historically, this isolation process was destructive, although non-destructive techniques for the 
generation of human embryonic stem cell lines have been proposed ${ }^{21}$. Pluripotent cells can be differentiated into any cell type within the body, but they are incapable of forming a viable embryo. Multipotent cells are capable of differentiating into a limited number of different cell types.

\section{The Edinburgh Patent}

The first major occasion on which the EPO had to consider the wording of the Article 6(2)(c) exclusion was the famous Edinburgh patent case. European patent no. 0695351 ("the Edinburgh patent") is entitled "Isolation, selection and propagation of animal transgenic stem cells". The Edinburgh patent originally described a method of using genetic engineering to isolate stem cells, including embryonic stem cells, from differentiated cells in culture in order to obtain pure stem cell cultures. The Edinburgh patent was initially granted with claims that covered human embryonic stem cells, whereupon it was opposed by fourteen parties, including Greenpeace and the governments of Germany, Italy and the Netherlands. In the course of the opposition proceedings, the EPO's Opposition Division was called upon to interpret various provisions of the European Biotechnology Patent Directive.

In particular, the Opposition Division considered that a broad interpretation of Article 6(2)(c) was appropriate, the reason being that a narrow interpretation of Article 6(2)(c) would render it redundant over Article 5(1). With a broad interpretation, the exclusion from patentability in Article 6(2)(c) was a prohibition that not only prevented the granting of patents covering the use of human embryos, but also patents covering any products derived from the use of human embryos.

In summary, the Opposition Division maintained that if the use of a human embryo is ethically unacceptable - as specified in Article 6(2)(c) - then any potentially inventive method or process that involves the prior use of a human embryo must also be ethically unacceptable. As a result, the owner of the Edinburgh patent decided to limit the patent claims to a method for genetically modifying stem cells (such as human adult stem cells). The EPO agreed that the patent could be maintained in that form. The proprietor initially decided to appeal this decision, but the appeal was withdrawn at a hearing before the EPO Board of Appeal in November $2007^{22}$. As a result, the moral and ethical issues wrapped up in any detailed consideration of the validity and legal scope of Article 6(2)(c) were effectively parked for another day.

\section{The WARF Patent in Europe}

The invention described in European patent application 96903521.1 was directed to cell cultures comprising primate embryonic stem cells. The inventor claimed that these cultures had been obtained for the first time in a way that allowed the cells to be cultured continuously for long periods whilst maintaining their ability to differentiate. The patent application stated that pluripotent stem cells that were obtained using the invention could be useful, both as models for human genetic diseases and in tissue transplantation for a wide variety of conditions.

The EPO's Examining Division acknowledged that the patent application met all of the substantive requirements for patentability: novelty, inventive step and industrial applicability. It refused the application on the grounds that the prohibition in Article $6(2)$ (c) excludes from patentability not only uses of human embryos, but also any product which originates from human embryos, where the isolation of that product 
requires the direct and unavoidable use of a human embryo. In its written decision, it stated as follows:

"The Examining Division takes the view that the application discloses and claims cultures of primate, including human, embryonic stem cells which cultures necessitate the use of an embryo and specific culture conditions for their generation and thus, said cultures integrate the industrial use of human embryos. Thus, the subject-matter....is not patentable under [Article 6(2)(c)] and the application is refused" 23 .

WARF appealed the Examining Division's decision, citing "countless problems" with the broad construction of the exclusion in Article 6(2)(c), including the argument that such an interpretation runs contrary to established EPO caselaw under the general morality exclusion in the European Patent Convention ${ }^{24}$ and that it requires the EPO to act as a moral censor. On the other hand, Article 6(2)(c) must exclude something from patentability. It has been noted that a narrow construction of Artcle 6(2)(c) that is limited to a prohibition on repetitive uses of an embryo as an instrument in an industrial process lacks conviction, because it does not correspond to anything within the contemplation of those responsible for the drafting of the Biotechnology Patent Directive or indeed anything within current knowledge and experience ${ }^{25}$.

The appeal thus raised a number of questions relating to the correct legal interpretation of the exclusion in Article 6(2)(c) of the European Biotechnology Patent Directive ${ }^{26}$. Following submissions made by various parties (including the President of the EPO) and a hearing in June 2008, a ruling by the EPO's Enlarged Board of Appeal was made on 25 November $2008^{27}$.

\section{“No Room For Manoeuvre"}

The Enlarged Board proceeded on the basis that it should examine the ordinary meaning of the exclusion, in the light of its objective and purpose. It therefore analysed the early drafts of the Biotechnology Patent Directive and its chequered legislative history. It derived from these documents concern that the Biotechnology Patent Directive might encourage human embryos to be commodified and it noted opposition by European Parliamentarians to practices involving the "misuse" of human embryos. These concepts are somewhat vague, but the Enlarged Board considered them to be consistent with one of the main objectives of the Directive that was ultimately codified in the final text, which is the protection of human dignity, in the patenting context ${ }^{28}$.

The Enlarged Board considered that the prima facie meaning of the exclusion was clear: it prohibited patenting, if a human embryo must be used for industrial or commercial purposes:

"making the [claimed product in the WARF patent] involves the destruction of human embryos. This use involving destruction is an integral and essential part of the industrial or commercial exploitation of the claimed invention, and thus violates the prohibition [in Article 6(2)(c)]"

It concluded that the exclusion forbids the patenting of claims to products that can

Genomics, Society and Policy, Vol.4, No.3 (2008) ISSN: 1746-5354

(C) ESRC Genomics Network. 
only be made by a method which involves the destruction of human embryos. There was "no room for manoeuvre". It did not matter that the use of a human embryo was not actually claimed, nor was it of relevance that technical developments subsequent to the date of filing of the patent application meant that the destruction of human embryos was now unnecessary ${ }^{29}$, in order to make products falling within the claims.

The patentee sought a reference to the European Court of Justice for clarification of the meaning of Article 6(2)(c), but this was refused by the Enlarged Board, essentially because the EPO Boards of Appeal do not qualify as courts competent to make such a referral.

\section{Conclusions}

The patentability of stem cell technology - specifically, technology relating to human embryonic stem cells - varies between the US and Europe because of a uniquely European legal provision concerning the moral and ethical status of inventions. Even though the Enlarged Board was at pains to point out that the WARF decision was not concerned in general with inventions relating to human stem cells or human stem cell cultures, the high-profile nature of a case such as this (and the previous Edinburgh patent decision) inevitably influences opinion. As a result, companies may come to see the US as a safer place to exploit stem cell technology ${ }^{30}$, thus potentially altering the competitive landscape in America's favour.

Although there are divergent views across the European Union on stem cell research and human embryonic stem cell studies in particular, the various governments of the Member States cannot have intended with the Biotechnology Patent Directive to surrender the policy decision about whether to grant patents in an important field of new technology to the EPO. Yet because the EPO is the de facto venue of choice for companies seeking patent protection in Europe and its decisions cannot be reviewed by the European courts, it effectively has the last word on whether to turn down a patent on moral or ethical grounds, with effect throughout the whole of the European Union and beyond $^{31}$. The European Court of Justice will only now get its say if there is a reference to it from a national court, by means of an appeal from a decision of a national patent office on a locally applied-for patent application in a Member State.

Patentees have already engaged in imaginative drafting strategies in order to circumvent anticipated difficulties in patent prosecution at the $\mathrm{EPO}^{32}$, but it seems likely that the European prohibition will inevitably impose some measure of competitive disadvantage upon all companies and institutions active in this sector of the life sciences ${ }^{33}$.

In conclusion, whilst in the US the patent system presents a reasonably level playing field, irrespective of the field of technology, with well understood criteria for the grant of monopoly rights of exploitation, those seeking patent protection in Europe in the area of stem cell technology (and particularly human stem cell cultures) are having to grapple with an additional legal hurdle based on the elusive notion of a European standard of "moral acceptability". In addition, the system is being administered by a centralised patent granting office - the EPO - that is arguably ill suited to the task of assessing inventions according to such an imprecise legal standard and moreover has no defined role in the formulation of EU industrial policy 
${ }^{1}$ Dr Duncan Curley, Innovate Legal (www.innovatelegal.co.uk), London duncancurley@innovatelegal.co.uk

${ }^{2}$ For example, see C. Holden. Prominent Researchers Join the Attack on Stem Cell Patents. Science 2007; 317: 187.

${ }^{3}$ J.A. Thomson, J. Itskovitz-Eldor \& S. S. Shapiro. Embryonic stem cell lines derived from human blastocysts. Science 1998; 282: 1145-1147.

${ }^{4}$ K. Bergman \& G.D. Graff. The global stem cell patent landscape: implications for efficient technology transfer and commercial development. Nature Biotechnology 2007; 25(4): 419-424.

${ }^{5}$ L.A. Haile \& S. Taylor. USPTO Rejects WARF's ESC Patents. Genetic Engineering \&

Biotechnology News 2007; 27(14):

http://www.genengnews.com/articles/chitem...aspx?aid $=2180 \&$ chid $=0$

${ }^{6}$ European Group on Ethics in Science and New Technologies. 2002. Ethical Aspects of Patenting Inventions Involving Human Stem Cells. Opinion no. 16 (7 May):

http://ec.europa.eu/european_group ethics/publications/docs/avis16 complet en.pdf

${ }^{7}$ For example, by the EPO's Opposition Division in a written decision on the Edinburgh patent case (supra).

${ }^{8}$ The requirement of sufficiency - see for example the helpful explanation of Lord Hoffmann in KirinAmgen v Hoechst Marion Roussel Ltd. [2005] RPC 9.

${ }^{9}$ R.S. Crespi. Stem cell patenting in Europe: the approaching climax. Expert Opin. Ther. Patents 2007; 17(1): 1-10.

${ }^{10}$ European Directive 98/44/EC on the Legal Protection of Biotechnological Inventions.

${ }^{11}$ Article 5(2).

${ }^{12}$ For example, the English Statute of Monopolies 1624: see E. Armitage \& I. Davis. 1994. Patents and Morality in Perspective. London: Common Law Institute of Intellectual Property.

${ }^{13}$ Note also Recital (40): Whereas there is a consensus within the Community that interventions in the human germ line and the cloning of human beings offends against ordre public and morality; whereas it is therefore important to exclude unequivocally from patentability processes for modifying the germ line genetic identity of human beings and processes for cloning human beings.

${ }^{14}$ G. Kamstra et al. 2002. Patents on Biotechnological Inventions: The E.C. Directive. Sweet \& Maxwell.

${ }^{15}$ For discussion, see A. Sharples \& D. Curley. Death of the Oncomouse. BioScience Law Review 2005; 8(3): 120-122.

${ }^{16}$ See Kamstra et al, op. cit. note 14; and the discussion in D. Curley \& A. Sharples. Patenting Biotechnology in Europe: The Ethical Debate Moves On. EIPR 2000; 24(12): 565-570.

${ }^{17}$ Case C-377/98: Kingdom of the Netherlands $v$ Council of the European Union and the European Parliament, All ER (EC) 97 (2002). For a summary of the decision, see D. Curley \& A .Sharples. European Court of Justice rejects Dutch challenge to the Biotech Directive. Patent World December 2001/January 2002: 9 .

${ }^{18} \mathrm{See} \mathrm{http://www.patent.gov.uk/patent/notices/practice/stemcells.htm}$

${ }^{19}$ Article 53(a) of the EPC, which originated in the negotiations that led to the Convention on the unification of certain points of substantive law on patents for inventions (The Strasbourg Convention) 1963.

${ }^{20}$ For example, in case T19/90 (Harvard Oncomouse), OJEPO (1990), 12, 476.

${ }^{21}$ I. Klimanskaya et al. Human embryonic stem cell lines derived from single blastomeres. Nature 2006; 444: 481-485.

${ }^{22}$ See the European Patent Office press release: http://www.epo.org/topics/news/2007/20071120a.html.

${ }^{23}$ In a decision dated 13 July 2004.

${ }^{24}$ For example, in the Oncomouse decision (op. cit. note 20) and in T365/96 Plant Genetic Systems (1995), OJEPO, 8, 545-585.

${ }^{25}$ See Crespi, op. cit. note 9.

${ }^{26}$ For discussion, see D. Curley \& A. Sharples. Ethical questions to ponder in the European Stem Cell

Patent Debate. Journal of Biolaw and Business 2006; 9(3): 12-16.

${ }^{27}$ See http://www.epo.org/topics/news/2008/20081127.html

${ }^{28}$ See Recital (16): Whereas patent law must be applied so as to respect the fundamental principles safeguarding the dignity and integrity of the person... 
${ }^{29}$ See Klimanskaya et al, op. cit. note 21.

${ }^{30}$ For example, in a UK Department of Trade and Industry Global Watch Mission Report published in September 2006, it was noted that there was concern amongst US companies about the uncertainties of European patenting on embryonic cell-related subjects.

${ }^{31}$ The national patent office route is not apparently being taken up on a major scale: see G. Porter et al. The patentability of human embryonic stem cells in Europe. Nature Biotechnology 2006; 24(6): 653655.

${ }^{32}$ See Porter et al, ibid.

${ }^{33}$ Comment made by the author in Time to re-examine the role of bioethics in the modern European patent system, Genomics and Society: Today's Answers, Tomorrow's Questions (Poster Abstract) (October 2007). 